\title{
CRITICAL HEAT FLUX DETERMINATION OF ELECTRIC CABLE INSULATION
}

\author{
Peter RANTUCH, Tomáš ŠTEFKO, Jozef MARTINKA \\ SLOVAK UNIVERSITY OF TECHNOLOGY IN BRATISLAVA, \\ FACULTY OF MATERIALS SCIENCE AND TECHNOLOGY IN TRNAVA, \\ INSTITUTE OF INTEGRATED SAFETY, \\ UliCA JÁNA BOTTU 2781/25, 91724 TRNAVA, SLOVAK REPUBLIC \\ e-mail: peter.rantuch@stuba.sk, tomas.stefko@stuba.sk, jozef.martinka@stuba.sk \\ Received: 23.04.2018, Accepted: 02.07.2018, Published: 19.09.2018
}

\begin{abstract}
Electric cables can contribute to the spread of fire through the insulating layer. This paper focuses on their properties characterizing the initiation of fire. Samples of ethylene-based cable insulation were tested using a cone calorimeter by exposing them to external heat flows of six different values $\left(25 \mathrm{~kW} \mathrm{~m}^{-2}-50 \mathrm{~kW} \mathrm{~m}^{-2}\right)$. Time to initiate flame burning was observed. The critical heat flux (depending on the method of calculation was in the range $2.94 \mathrm{~kW} \mathrm{~m}^{-2}-4.59$ $\left.\mathrm{kW} \mathrm{m}^{-2}\right)$ and the thermal response parameter $\left(342 \mathrm{~kW} \mathrm{~s}^{-0.5} \mathrm{~m}^{-2}\right)$ was calculated from the time of initiation and external heat flow dependence.
\end{abstract}

\section{Key words}

Cone calorimeter, time to ignition, critical heat flux, thermal response parameter

\section{INTRODUCTION}

Electrical cables are used extensively for both residential and industrial applications. They consist of conductors made of either copper or aluminium and insulation (or jackets) of synthetic polymeric materials. Several types of polymeric materials are used in cable constructions, varying in chemical structure, thickness, and additives. Depending on the applications, cables are either packed loosely or tightly, in horizontal, vertical or other orientations. (Tewarson, 1989) Electrical cables are complex assemblies including several polymeric parts (insulation, bedding, sheath) constituting fuel sources. Its fire behaviour is highly dependent on the heat flux. A dramatic transition occurs at a different heat flux according to the cable. (Meinier, et al., 2018) Ignition and burning of electrical cables are potential causes of fires in residential or industrial buildings. Moreover, cables may also lose their functions or be less efficient when exposed to heat sources (progressive change in resistance, deterioration of the signal quality, short-cut). (Courty, 2017)

Depending on their location and means of installation, cables can contribute to a fire in several ways. For example, burning cables can propagate flames from one area to another, can 
add to the fuel available for combustion and can liberate smoke and toxic and corrosive gases. The hazard from burning cables should be put in the context of the surroundings. Sometimes, cables form a very small proportion of the combustible material, while in other situations they can form the majority. (Moore, 2000.)

Halogen containing materials, as a group, tend to outperform non-halogen materials in terms of the major fire properties (Barnes et al., 1996):

- Heat release

- Ignitability

- Flammability

To produce materials formulated to meet the various insulation or jacketing performance requirements (e.g., heat and light stability, smoke retardancy, or water resistance), polymers and additives are combined together in a compounding operation. (Harriman, 2002.)

Additives represent a broad range of chemicals used by resin manufacturers, compounders, and fabricators to improve the properties, processing, and performance of polymers. From the earliest days of the plastics industry, additives have been used initially to aid these materials in processing and then to improve their properties. (Harper, 2000.)

Henrist et al. (2000) carried out interdiffusion experiments must simulate the behaviour of the cable constituents in controlled conditions. As reactants, they used either the commercially available product or a similar chemical composition. The reactant powders were ground together, placed in alumina or platinum crucibles and heated following the conditions summarized in Table 1.

\begin{tabular}{|c|c|c|}
\hline Reactants & $\begin{array}{c}\text { Temperature } \\
\text { of treatment } \\
{\left[{ }^{\circ} \mathrm{C}\right]}\end{array}$ & Identified products of reaction \\
\hline $\begin{array}{l}\text { Alumina trihydrate } \\
\text { Zinc borate }\end{array}$ & 900 & $\begin{array}{l}2 \mathrm{ZnO} .3 \mathrm{~B}_{2} \mathrm{O}_{3} \cdot 3,5 \mathrm{H}_{2} \mathrm{O}+4 \mathrm{Al}(\mathrm{OH})_{3} \rightarrow 2 \mathrm{ZnAl}_{2} \mathrm{O}_{4}+ \\
9,5 \mathrm{H}_{2} \mathrm{O}+3 \mathrm{~B}_{2} \mathrm{O}_{3}\end{array}$ \\
\hline $\begin{array}{l}\text { Zinc borate } \\
\text { Silicon dioxide }\end{array}$ & 1180 & No reaction \\
\hline \multirow{2}{*}{$\begin{array}{l}\text { Silicon dioxide } \\
\text { Alumina trihydrate }\end{array}$} & 1180 & No reaction \\
\hline & 1400 & $3 \mathrm{Al}_{2} \mathrm{O}_{3}+2 \mathrm{SiO}_{2} \rightarrow \mathrm{Al}_{6} \mathrm{Si}_{2} \mathrm{O}_{13}$ \\
\hline $\begin{array}{l}\text { Copper } \\
\text { Alumina trihydrate }\end{array}$ & 900 & $\begin{array}{l}\mathrm{Cu}+2 \mathrm{Al}(\mathrm{OH})_{3}+0,5 \mathrm{O}_{2} \rightarrow \mathrm{CuAl}_{2} \mathrm{O}_{4}+3 \mathrm{H}_{2} \mathrm{O} \\
2 \mathrm{Cu}+2 \mathrm{Al}(\mathrm{OH})_{3}+0,5 \mathrm{O}_{2} \rightarrow 2 \mathrm{CuAlO}_{2}+3 \mathrm{H}_{2} \mathrm{O} \\
\mathrm{Cu}+0,5 \mathrm{O}_{2} \rightarrow \mathrm{CuO}\end{array}$ \\
\hline $\begin{array}{l}\text { Copper } \\
\text { Alumina trihydrate } \\
\text { Zinc borate }\end{array}$ & 900 & $\begin{array}{l}2 \mathrm{ZnO} .3 \mathrm{~B}_{2} \mathrm{O}_{3} \cdot 3,5 \mathrm{H}_{2} \mathrm{O}+4 \mathrm{Al}(\mathrm{OH})_{3} \rightarrow 2 \mathrm{ZnAl}_{2} \mathrm{O}_{4}+ \\
9,5 \mathrm{H}_{2} \mathrm{O}+3 \mathrm{~B}_{2} \mathrm{O}_{3} \\
2 \mathrm{Cu}+\mathrm{O}_{2}+2 \mathrm{ZnO} \cdot 3 \mathrm{~B}_{2} \mathrm{O}_{3} \cdot 3,5 \mathrm{H}_{2} \mathrm{O}+6 \mathrm{Al}(\mathrm{OH})_{3} \rightarrow \\
\mathrm{Cu}_{2} \mathrm{~A}_{16} \mathrm{~B}_{4} \mathrm{O}_{17}+\mathrm{B}_{2} \mathrm{O}_{3}+2 \mathrm{ZnO}+12,5 \mathrm{H}_{2} \mathrm{O}\end{array}$ \\
\hline $\begin{array}{l}\text { Copper oxide } \\
\text { Boric acid }\end{array}$ & 900 & $3 \mathrm{CuO}+2 \mathrm{H}_{3} \mathrm{BO}_{3} \rightarrow \mathrm{Cu}_{3} \mathrm{~B}_{2} \mathrm{O}_{6}+3 \mathrm{H}_{2} \mathrm{O}$ \\
\hline $\begin{array}{l}\text { Copper } \\
\text { Zinc borate }\end{array}$ & 950 & $\begin{array}{l}\text { Dendritic copper oxide } \\
\text { No copper borate }\end{array}$ \\
\hline $\begin{array}{l}\text { Copper } \\
\text { Zinc borate } \\
\text { Silicon dioxide }\end{array}$ & 900 & $\begin{array}{l}\text { Dendritic copper oxide } \\
\text { No chemical association of } \mathrm{Cu}, \mathrm{Zn} \text { and } \mathrm{Si}\end{array}$ \\
\hline
\end{tabular}

The cone calorimeter is likely to be adequate to address the fire hazard associated with fires and electrical cables in scenarios where cables are the main (or sole) combustibles. (Hirschler, 1994) 


\section{METHODS AND MATERIALS}

The test samples were commercially available electric cable CHKE-V J3x1.5 PS60 B2ca with a total thickness of $9 \mathrm{~mm}$ produced by VUKI a.s.. The manufacturer states that it is a power cable with increased flame spread resistance. It is halogen-free, it meets the requirements for the B2ca fire reaction class (s1d1) and is functional in the fire for 180 minutes. It is designed for fixed placement in ordinary and humid environments. Cables can also be used in environments with a fire hazard and can be installed on flammable surfaces. (http://www.vuki.sk)

Aim of the paper was to evaluate time to ignition of the samples. Samples were exposed to external heat flow from cone calorimeter (Figure 1), with six different values: $25 \mathrm{~kW} \mathrm{~m}^{-2}$, $30 \mathrm{~kW} \mathrm{~m}^{-2}, 35 \mathrm{~kW} \mathrm{~m}^{-2}, 40 \mathrm{~kW} \mathrm{~m}^{-2}, 45 \mathrm{~kW} \mathrm{~m}^{-2}$ and $50 \mathrm{~kW} \mathrm{~m}^{-2}$. Samples were prepared by cutting the cable to $10 \mathrm{~cm}$ pieces and placed close to each other on $10 \mathrm{~cm} \times 10 \mathrm{~cm}$ aluminium foil. Prepared sample (2) was inserted into the sample holder (1) and placed under the cone heater (4). Spark igniter (3) was located $13 \mathrm{~mm}$ above the sample. The resulting gaseous products of thermal decomposition of samples were aspirated by electric fan (6) through the hood of calorimeter (5). Initiation of the samples was monitored visually.

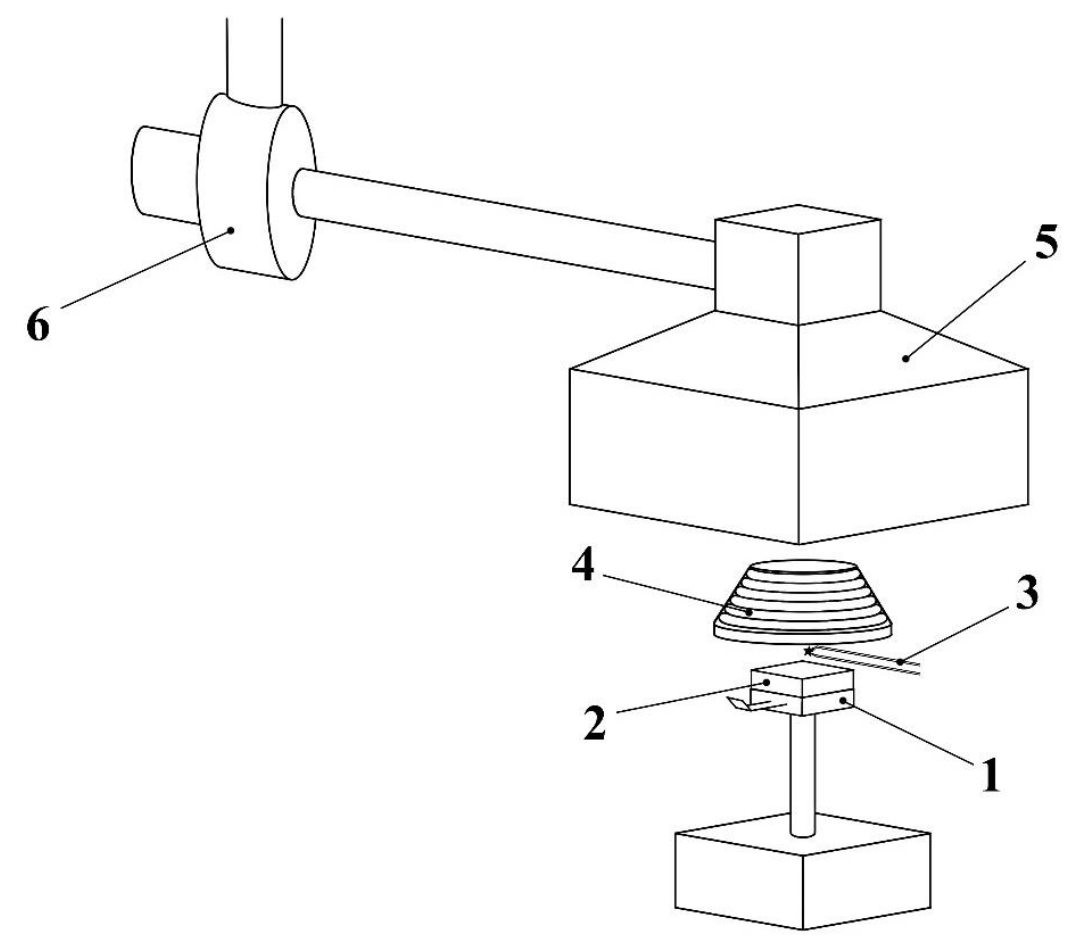

Fig. 1 Test device: 1 - holder of sample, 2 - sample, 3 -spark igniter, 4 -cone heater, 5 -hood, 6 -fan (Rantuch et al., 2016)

\section{CRITICAL HEAT FLUX AND THERMAL RESPONSE PARAMETER}

Critical heat flux is minimum heat flux at or below which there is no ignition, and thermal response parameter (TRP) should be defined as resistance to ignition and flame spread. It is a combination of ignition temperature above ambient, thermal conductivity, specific heat, and density of the material. Higher critical heat flux and TRP values suggest that materials are hard to ignite and have higher flame spread resistance. In general, thermosets have higher TRP values than the thermoplastics. (Tewarson, 1994) Typically, the critical heat flux values are determined by exposing the horizontal sample (e.g., about $100 \mathrm{~mm}$ diameter or about $100 \mathrm{~mm}$ 
$\mathrm{x} 100 \mathrm{~mm}$ square and up to about $100 \mathrm{~mm}$ in thickness with blackened surface in the flammability apparatus) to various external heat flux values until a value is found at which there is no ignition for about $15 \mathrm{~min}$. The value of TRP for a surface that is not blackened is higher than the value for the blackened surface. (Tewarson, 2002)

The heat flux for the vertical orientation is averagely $15 \%$ higher than that for the horizontal orientation. This is caused primarily by the effect of concurrent direction of entrained air and pyrolysis gas flow for the vertically oriented samples, which significantly dilutes the flammable vapours. Therefore, to achieve enough concentration of flammable vapours for ignition, the critical heat flux for pilot ignition for vertical samples is higher. (Tsai, 2009)

Critical heat flux can be determined by calculation based on dependence of sample ignition time on external heat flux. This dependence can vary as each material has different parameters and characteristics. In Table 2, there is an overview of some identified relations for critical heat flux calculation for different materials.

\begin{tabular}{|c|c|c|}
\hline Function $q_{e}$ & Suitability of use & Source \\
\hline \multirow[b]{2}{*}{$\mathrm{q}_{\mathrm{e}}=\mathrm{f}\left(\frac{\mathrm{t}}{\mathrm{t}_{\mathrm{i}} \frac{2}{3}}\right)$} & Wood, pilot ignition & $\begin{array}{c}\text { (Lawson, Simms, } \\
\text { 1952) }\end{array}$ \\
\hline & Thermally intermediate material & $\begin{array}{c}\text { (Mikkola, } \\
\text { Wichman, 1989) }\end{array}$ \\
\hline $\mathrm{q}_{\mathrm{e}}=\mathrm{f}\left(\frac{1}{\mathrm{t}_{\mathrm{i}^{\frac{4}{5}}}}\right)$ & Wood, spontaneous ignition & $\begin{array}{c}\text { (Lawson, Simms, } \\
\text { 1952) }\end{array}$ \\
\hline $\mathrm{q}_{\mathrm{e}}=\mathrm{f}\left(\frac{1}{\mathrm{t}_{\mathrm{i}^{\frac{1}{2}}}}\right)$ & Thermally thick material & $\begin{array}{c}\text { (Mikkola, } \\
\text { Wichman, 1989) }\end{array}$ \\
\hline \multirow{3}{*}{$\mathrm{q}_{\mathrm{e}}=\mathrm{f}\left(\frac{1}{\mathrm{t}_{\mathrm{i}}}\right)$} & $\begin{array}{c}\text { For plasterboard: } 30 \mathrm{~kW} \cdot \mathrm{m}^{2} \leq q_{e} \leq 40 \mathrm{~kW} \cdot \mathrm{m}^{2} \\
\text { pilot ignition }\end{array}$ & \multirow[t]{2}{*}{ (Bluhme, 1987) } \\
\hline & $\begin{array}{c}\text { For wood: } 20 \mathrm{~kW} \cdot \mathrm{m}^{-2} \leq q_{e} \leq 30 \mathrm{~kW} \cdot \mathrm{m}^{-2} \\
\text { pilot ignition }\end{array}$ & \\
\hline & Thermally thin materials & $\begin{array}{c}\text { (Mikkola, } \\
\text { Wichman, 1989) }\end{array}$ \\
\hline $\mathrm{q}_{\mathrm{e}}=\mathrm{f}\left(\frac{1}{\mathrm{t}_{\mathrm{i}}^{0,547}}\right)$ & Wood, piloted ignition & (Janssens, 1991) \\
\hline
\end{tabular}

According to Meinier et al. (2018) time to ignition of halogen-free flame retardant cables with an external diameter of $12 \mathrm{~mm}$, is well predicted by the so-called thermally thick model considering only the sheath properties.

\section{RESULTS AND DISCUSSION}

The results of the time to ignition measurements together with the weight of the individual samples are shown in Table 3. The measured values show that with increasing heat flow, time to ignition decreases. This is a generally known fact that is caused by the increasing amount of thermal energy incident to the surface of the samples. This energy is divided into three components: 
1. Component reflected to the environment, which depends on the emissivity of the sample

2. Component drawn into the interior of the sample, which depends on the thermal conductivity of the test material

3. Component absorbed by a thin surface layer, which depends on the thermal properties of the loaded material.

Due to the increasing temperature, thermal degradation of the surface layer and the release of gaseous flammable substances occurs. Upon reaching a sufficient temperature and concentration of their mixture with air, initiation of flame burning occurs.

\begin{tabular}{|c|c|c|}
\hline \multicolumn{3}{|c|}{ Table 3: Measured values of time to ignition } \\
\hline Heat flux [kW $\left.\mathbf{~ m}^{-2}\right]$ & Sample weight $[\mathbf{g}]$ & Time to initiation $\mathbf{~ s ] ~}$ \\
\hline 25 & 150.1 & 181 \\
\hline 30 & 150.8 & 136 \\
\hline 35 & 149.9 & 91 \\
\hline 40 & 153.0 & 68 \\
\hline 45 & 148.6 & 45 \\
\hline 50 & 148.2 & 43 \\
\hline
\end{tabular}

Based on relations shown in Table 2, graphs of corresponding dependencies were created (Fig. 2). Trend lines were plotted in each graph to evaluate the linear dependence of parameters. The relevant equations of linear regression and squares of correlation coefficients are shown in Table 4.

\begin{tabular}{|c|c|c|}
\hline \multicolumn{3}{|c|}{$\begin{array}{c}\text { Table 4: Equations of trend lines and squares of correlation coefficients of various } \\
\text { dependences of external heat flux and time to ignition }\end{array}$} \\
\hline Function $q_{e}$ & $\begin{array}{c}\text { Linear regression } \\
\text { equation }\end{array}$ & Square of correlation coefficient $[-]$ \\
\hline $\mathrm{q}_{\mathrm{e}}=\mathrm{f}\left(\frac{1}{\mathrm{t}_{\mathrm{i}} \frac{2}{3}}\right)$ & $\mathrm{y}=0.0021 \mathrm{x}-0.0235$ & 0.9924 \\
\hline $\mathrm{q}_{\mathrm{e}}=\mathrm{f}\left(\frac{1}{\mathrm{t}_{\mathrm{i}} \frac{4}{5}}\right)$ & $\mathrm{y}=0.0014 \mathrm{x}-0.0215$ & 0.9900 \\
\hline $\mathrm{q}_{\mathrm{e}}=\mathrm{f}\left(\frac{1}{\mathrm{t}_{\mathrm{i}} \frac{1}{2}}\right)$ & $\mathrm{y}=0.0033 \mathrm{x}-0.0097$ & 0.9940 \\
\hline $\mathrm{q}_{\mathrm{e}}=\mathrm{f}\left(\frac{1}{\mathrm{t}_{\mathrm{i}}}\right)$ & $\mathrm{y}=0.0007 \mathrm{x}-0.0143$ & 0.9843 \\
\hline $\mathrm{q}_{\mathrm{e}}=\mathrm{f}\left(\frac{1}{\mathrm{t}_{\mathrm{i}}^{0,547}}\right)$ & $\mathrm{y}=0.0029 \mathrm{x}-0.0169$ & 0.9937 \\
\hline
\end{tabular}


a)

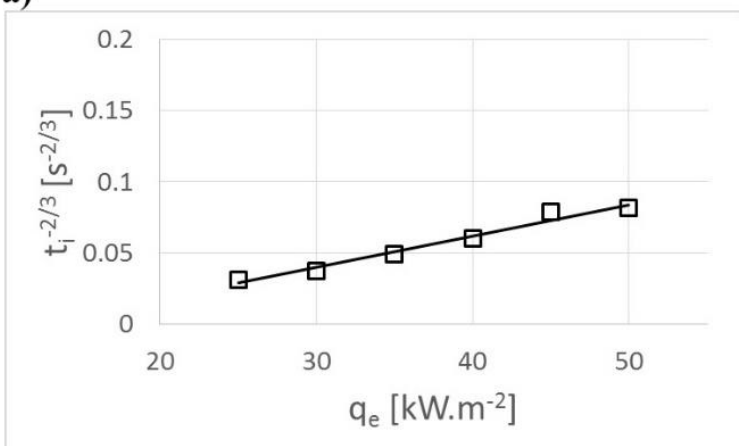

c)

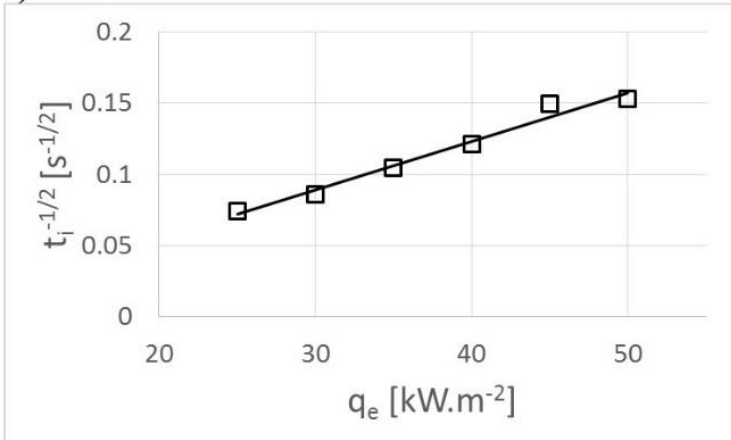

b)

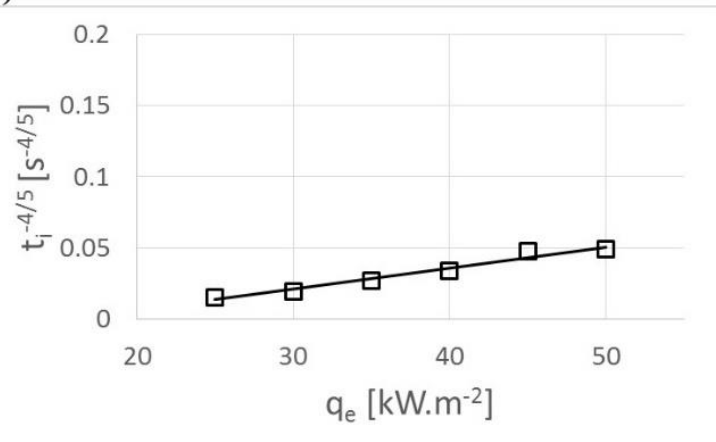

d)

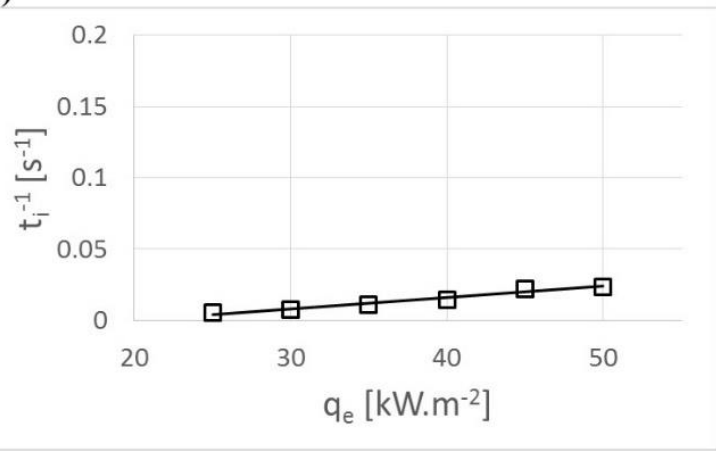

e)

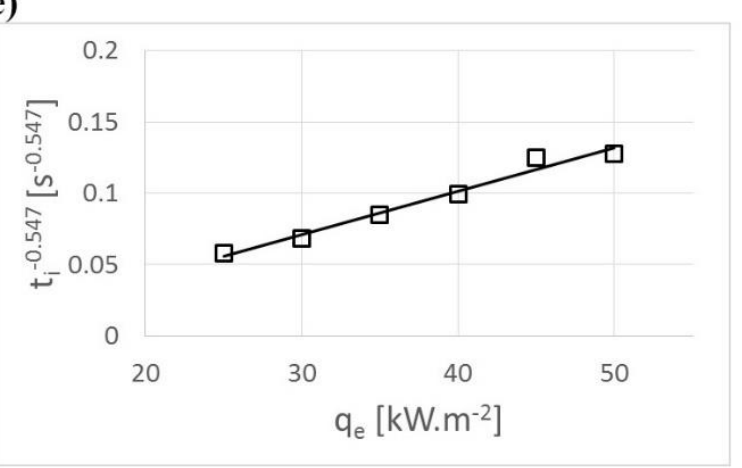

Fig. 2 Graphs of various dependences of external heat flux and time to ignition: a) $q_{e} v s t_{i}^{-\frac{2}{3}}$; b)

$$
\left.\left.\left.q_{e} v s t_{i}^{-\frac{4}{5}} ; \mathrm{c}\right) q_{e} v s t_{i}^{-\frac{1}{2}} ; \mathrm{d}\right) q_{e} v s t_{i}^{-1} ; \mathrm{d}\right) q_{e} v s t_{i}^{-0,547}
$$

Due to the suitability of various dependencies (Table 2) and squares of correlation coefficients (Table 4), the most appropriate dependence is $q_{e} v s t_{i}^{-\frac{1}{2}}$. Calculation of this dependence is used in the paper of Fateh et al. (2014). The basic equation takes the form:

$$
t_{i}=\frac{\pi}{4} k \rho c\left(\frac{T_{i}-T_{0}}{q_{e}-q_{c r}}\right)^{2}
$$

where $\mathrm{t}_{\mathrm{i}}$ is time to ignition, $k$ is thermal conductivity, $\rho$ is density, $c$ is heat capacity, $T_{i}$ is ignition temperature, $T_{0}$ is ambient temperature, $\mathrm{q}_{\mathrm{e}}$ is external heat flux and $\mathrm{q}_{\mathrm{cr}}$ is critical heat flux. The equation can be further modified as follows: 


$$
\begin{gathered}
T R P=\left(T_{i}-T_{0}\right) \sqrt{k \rho c} \\
\sqrt{\frac{1}{t_{i}}}=\frac{2}{\sqrt{\pi}} \frac{\left(q_{e}-q_{c r}\right)}{T R P},
\end{gathered}
$$

where TRP is thermal response parameter. The values of critical heat flux and thermal response parameter can be calculated as:

$$
\begin{gathered}
q_{c r}=-\frac{T R P \cdot y_{\text {intercept }}}{\sqrt{\frac{4}{\pi}}} \\
T R P=\sqrt{\frac{4}{\pi}} \frac{1}{\text { Slope }},
\end{gathered}
$$

where $y_{\text {intercept }}$ is interception of trend line with y-axis.

Delichatsios et al. (1991) developed equation, which relate the time to ignition to the imposed heat flux in standard flammability test measurements, where surface reradiation losses are significant:

$$
\frac{1}{\sqrt{t_{i}}}=\frac{2}{\sqrt{\pi k \rho c}\left(T_{i}-T_{0}\right)}\left[q_{e}-0,64 q_{c r}\right] .
$$

Calculated values of critical heat fluxes and thermal response parameters are shown in Table 5. In the table are also shown results from other authors to compare their findings. In the terms of critical heat flow, a relatively low value was observed for the investigated electrical cable, which is virtually identical to the polymethyl methacrylate tested by Rhodes and Quintiere (1996). In contrast, the thermal response parameter is very high compared to other materials. Therefore, it can be stated that flame spread resistance to of the tested cable is given by the value of its TRP.

Coutry and Garo (2017) tested two types of electric cables in the furnace of circular crosssection. Their values for the critical heat flux are twofold compared to the results of this study and the value of the thermal response parameter is about half of this study result. These differences can be caused by different insulation materials of the tested cables as well as another used methodology. While this study describes the effect of the heat flow on one side of more cables next to each other, mentioned authors studied effect of heat flux on the whole surface of single cable in a vertical position. 
Table 5: Critical heat fluxes and thermal response parameters of various materials (* $\mathrm{H}$ - horizontal; $\mathrm{V}$ - vertical)

\begin{tabular}{|c|c|c|c|c|c|}
\hline 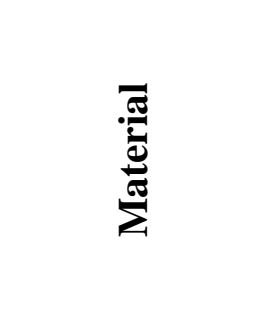 & مَّ & 葛 & 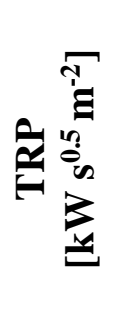 & : & 苞 \\
\hline Electric cable & $\mathrm{H}$ & 2.94 & 342 & $(1)$ & This study \\
\hline Electric cable & $\mathrm{H}$ & 4.59 & 342 & (6) & This study \\
\hline Plywood B & $\mathrm{H}$ & 11 & 136 & \multirow{2}{*}{$t_{i}=\frac{\pi}{4} k \rho c\left(\frac{T_{i}-T_{0}}{q_{e}-q_{c r}}\right)^{2}$} & \multirow{2}{*}{$\begin{array}{l}\text { (Fateh et al., } \\
\text { 2014) }\end{array}$} \\
\hline Plywood D & $\mathrm{H}$ & 10.5 & 124 & & \\
\hline \multirow{2}{*}{ PMMA } & $\mathrm{H}$ & 9.2 & 250.8 & \multirow{6}{*}{$t_{i}=\frac{\pi}{4} k \rho c \frac{\left(T_{i}-T_{0}\right)^{2}}{Q_{R}^{2}}$} & \multirow{6}{*}{ (Tsai, 2009) } \\
\hline & $\mathrm{V}$ & 10.4 & 268.7 & & \\
\hline \multirow{2}{*}{$\begin{array}{l}\text { Polystyrene } \\
\text { foam } 10 \mathrm{~mm}\end{array}$} & $\mathrm{H}$ & 14.5 & 87.5 & & \\
\hline & $\mathrm{V}$ & 18.0 & 105.5 & & \\
\hline \multirow{2}{*}{$\begin{array}{l}\text { Polystyrene } \\
\text { foam } 20 \mathrm{~mm}\end{array}$} & $\mathrm{H}$ & 7.2 & 108.5 & & \\
\hline & $\mathrm{V}$ & 17.4 & 122.7 & & \\
\hline PMMA & $\mathrm{H}$ & 4 & - & $t_{i}=\frac{2}{3} k \rho c \frac{\left(T_{i}-T_{0}\right)^{2}}{q_{n e t}^{2}}$ & $\begin{array}{l}\text { (Rhodes, } \\
\text { Quintiere, } \\
1996)\end{array}$ \\
\hline Acrylic textile & $\mathrm{H}$ & 9 & - & \multirow{3}{*}{$\frac{1}{t_{i}}=A \cdot q_{e}+B$} & \multirow{3}{*}{$\begin{array}{c}\text { (Nazare et al., } \\
\text { 2002) }\end{array}$} \\
\hline $\begin{array}{c}\text { Heavy silk } \\
\text { textile }\end{array}$ & $\mathrm{H}$ & 12 & - & & \\
\hline Wool textile & $\mathrm{H}$ & 11 & - & & \\
\hline $\begin{array}{c}\text { Polyamide } 6 \\
\text { nanocomposit } \\
\mathrm{e} \\
\end{array}$ & $\mathrm{H}$ & 17.9 & - & ${ }^{t_{i}}=\frac{\pi}{4} k \rho c\left(\frac{T_{i}-T_{0}}{q_{e}-0.64 q_{c r}}\right)^{2}$ & $\begin{array}{l}\text { (Zhang et al., } \\
\text { 2009) }\end{array}$ \\
\hline $\begin{array}{c}\text { Expanded } \\
\text { polystyrene }\end{array}$ & $\mathrm{H}$ & $11.77-12.07$ & - & \multirow{2}{*}{$t_{i}=\frac{\pi}{4} k \rho c\left(\frac{T_{i}-T_{0}}{\varepsilon \cdot q_{e}}\right)^{2}$} & \multirow{2}{*}{$\begin{array}{l}\text { (An et al., } \\
\text { 2015) }\end{array}$} \\
\hline $\begin{array}{c}\text { Extruded } \\
\text { polystyrene }\end{array}$ & $\mathrm{H}$ & $\begin{array}{c}10.42- \\
10.82 \\
\end{array}$ & - & & \\
\hline Polypropylene & $\mathrm{H}$ & - & 291 & \multirow{4}{*}{$\sqrt{\frac{1}{t_{i}}}=\sqrt{\frac{4}{\pi}} \frac{q_{e}}{T R P}$} & \multirow{4}{*}{$\begin{array}{c}\text { (Tewarson, } \\
\text { 1994) }\end{array}$} \\
\hline Epoxy resin & $\mathrm{H}$ & - & 457 & & \\
\hline Epoxy kevlar & $\mathrm{H}$ & - & 169 & & \\
\hline $\begin{array}{c}\text { Polyvinyl } \\
\text { ester }\end{array}$ & $\mathrm{H}$ & - & 263 & & \\
\hline $\begin{array}{c}\text { EPR/HYPAL } \\
\text { ON cable }\end{array}$ & $\mathrm{V}$ & 9 & 166 & \multirow{2}{*}{$\sqrt{\frac{1}{t_{i}}}=\frac{\left(q_{i}-q_{c r}\right)}{T R P}$} & \multirow{2}{*}{$\begin{array}{c}\text { (Courty, Garo, } \\
\text { 2017) }\end{array}$} \\
\hline $\begin{array}{c}\mathrm{PVC} / \mathrm{PVC} \\
\text { cable }\end{array}$ & $\mathrm{V}$ & 6.2 & 141 & & \\
\hline
\end{tabular}




\section{CONCLUSION}

The paper deals with the initiation characteristics of an electric cable suitable for installation in a fire hazardous environment and on a flammable substrate. Time to ignition of samples at different values of the external heat flux was monitored. With increasing heat flow, time to ignition raised from 43 seconds $\left(50 \mathrm{~kW} \mathrm{~m}^{-2}\right)$ to 181 seconds $\left(25 \mathrm{~kW} \mathrm{~m}^{-2}\right)$.

Based on the obtained data as well as the use of various functions describing the dependence of external heat flux and time to ignition, external thermal flux and thermal response parameter were calculated. These two variables describe the behaviour of the materials in the initiation phase of the fire.

The calculated value of the external heat flux in dependence on the calculation method was $2.94 \mathrm{~kW} \mathrm{~m}^{-2}$ or $4.59 \mathrm{~kW} \mathrm{~m}^{-2}$ respectively. The value of the thermal response parameter was 342 $\mathrm{kW} \mathrm{s}{ }^{-0.5} \mathrm{~m}^{-2}$. According to these results, the flame spread resistance of the test cable is most dependent on its TRP value.

\section{Acknowledgements}

This contribution was supported by the Slovak Research and Development Agency under the contract No. APVV-16-0223.

\section{References:}

1. AN, W., JIANG, L., SUN, J., LIEW, K. M. 2015. Correlation analysis of sample thickness, heat flux, and cone calorimetry test data of polystyrene foam. Journal of Thermal Analysis and Calorimetry. 119(1). pp. 229-238.

2. BARNES, M. A., BRIGGS, P. J., HIRSCHLER, M. M., MATHESON, A. F., O'NEILL, T. J. 1996. A Comparative Study of the Fire Performance of Halogenated and Non-Halogenated Materials for Cable Applications. Part I Tests on Materials and Insulated Wires. Fire and Materials. 20(1). pp. $1-16$.

3. BLUHME, D. A. 1987. ISO ignitability test and proposed criteria. Fire and materials. 11(4). pp. 195-199.

4. COURTY, L., GARO, J. P. 2017. External heating of electrical cables and auto-ignition investigation. Journal of hazardous materials. 321. pp. 528-536.

5. DELICHATSIOS, M. A., PANAGIOTOU, T. H., KILEY, F. (1991). The use of time to ignition data for characterizing the thermal inertia and the minimum (critical) heat flux for ignition or pyrolysis. Combustion and Flame. 84(3-4). pp. 323-332.

6. FATEH, T., ROGAUME, T., LUCHE, J., FRANCK, R., JABOUILLE, F. 2014. Characterization of the thermal decomposition of two kinds of plywood with a cone calorimeter-FTIR apparatus. Journal of Analytical and Applied Pyrolysis. 107. pp. 87-100.

7. HARPER, C. A. 2000. Modern Plastics Handbook: Handbook. McGraw-Hill Professional.

8. HARRIMAN, L. 2002. Environmental, health and safety issues in the coated wire and cable industry. Greiner Environmental, Inc. Massachusetts Toxics Use Reduction Institute. University of Massachusetts Lowell. One University Ave. Lowell.

9. HENRIST, C., RULMONT, A., CLOOTS, R., GILBERT, B., BERNARD, A., BEYER, G. 2000. Toward the understanding of the thermal degradation of commercially available fire-resistant cable. Materials letters. 46(2-3). pp. 160-168.

10. HIRSCHLER, M. M. 1994. Comparison of large-and small-scale heat release tests with electrical cables. Fire and Materials. 18(2). pp. 61-76.

11. http://www.vuki.sk/sites/default/files/tmp/4_chke-v_b2cas1d1ps306090_sj_0.pdf_[04/18/2018]

12. JANSSENS, M. 1991. A thermal model for piloted ignition of wood including variable thermophysical properties. Fire Safety Science. 3. pp. 167-176

13. LAWSON, D. I., SIMMS, U. D. 1952. The ignition of wood by radiation. British Journal of Applied Physics. 3(9). pp. 288. 
14. MEINIER, R., SONNIER, R., ZAVALETA, P., SUARD, S., FERRY, L. 2018. Fire behavior of halogen-free flame retardant electrical cables with the cone calorimeter. Journal of hazardous materials. 342, pp. 306-316.

15. MIKKOLA, E., WICHMAN, I. S. 1989. On the thermal ignition of combustible materials. Fire and Materials. 14(3). pp. 87-96.

16. MOORE, G. F. (Ed.). (2000). Electric Cables Handbook: BICCCables. Blackwell Science.

17. NAZARE, S., KANDOLA, B., HORROCKS, A. R. 2002. Use of cone calorimetry to quantify the burning hazard of apparel fabrics. Fire and Materials. 26(4-5). pp. 191-199.

18. RANTUCH, P., HRUŠOVSKÝ, I. MARTINKA, J., BALOG, K. 2016. Determination of the critical heat flux and the corresponding surface ignition temperature of expanded cork plates. Wood \& Fire Safety: proceedings of the 8th International Conference. The High Tatras, Strbské Pleso, 8. - 12. May 2016. pp. 261-268.

19. RHODES, B. T., QUINTIERE, J. G. 1996. Burning rate and flame heat flux for PMMA in a cone calorimeter. Fire Safety Journal. 26(3). pp. 221-240.

20. TEWARSON, A. 1994. Flammability parameters of materials: ignition, combustion, and fire propagation. Journal of Fire Sciences. 12(4). pp. 329-356.

21. TEWARSON, A. 2002. Generation of heat and chemical compounds in fires. SFPE handbook of fire protection engineering.

22. TEWARSON, A., KHAN, M. M. 1989. Fire propagation behavior of electrical cables. Fire Safety Science. 2, pp. 791-800.

23. TSAI, K. C. 2009. Orientation effect on cone calorimeter test results to assess fire hazard of materials. Journal of hazardous materials. 172(2-3). pp. 763-772.

24. ZHANG, J., DELICHATSIOS, M. A., BOURBIGOT, S. 2009. Experimental and numerical study of the effects of nanoparticles on pyrolysis of a polyamide 6 (PA6) nanocomposite in the cone calorimeter. Combustion and Flame. 156(11). pp. 2056-2062.

\section{ORCID:}

Peter Rantuch $\quad$ 0000-0001-5826-8323

Jozef Martinka 0000-0002-0060-5785 